\title{
Knowledge translation: translating research into policy and practice
}

\author{
Translação do conhecimento: traduzindo pesquisa \\ para uso na prática e na formulação de políticas \\ Traslación del conocimiento: traduciendo investigación \\ para uso en la práctica y formulación de políticas
}

\author{
Nelly Donszelmann Oelke \\ Maria Alice Dias da Silva Lima ${ }^{b}$ \\ Aline Marques Acostab
}

DOl: $\quad$ http://dx.doi.org/10.1590/1983-

1447.2015.03.55036

\footnotetext{
a University of British Columbia, Okanagan Campus, Faculty of Health and Social Development, School of Nursing, Kelowna, Canada

b Universidade Federal do Rio Grande do Sul (UFRGS), Escola de Enfermagem, Porto Alegre, Rio Grande do Sul, Brasil.
}

\section{ABSTRACT}

Objective: This paper provides a theoretical-reflective study of knowledge translation concepts and their implementation processes for using research evidence in policy and practice.

Results: The process of translating research into practice is iterative and dynamic, with fluid boundaries between knowledge creation and action development. Knowledge translation focuses on co-creating knowledge with stakeholders and sharing that knowledge to ensure uptake of relevant research to facilitate informed decisions and changes in policy, practice, and health services delivery. In Brazil, many challenges exist in implementing knowledge translation: lack of awareness, lack of partnerships between researchers and knowledge-users, and low research budgets.

Conclusions: An emphasis on knowledge translation has the potential to positively impact health outcomes. Future research in Brazil is needed to study approaches to improve the uptake of research results in the Brazilian context.

Keywords: Information dissemination. Evidence-based practice. Policy making.

\section{RESUMO}

Objetivo: Estudo teórico reflexivo de conceitos de translação do conhecimento e seu processo de implementação para usar evidências de pesquisas na prática e na formulação de políticas.

Resultados: 0 processo de translação da pesquisa para a prática é interativo e dinâmico, com limites flexíveis entre criação do conhecimento e desenvolvimento das ações. A translação do conhecimento enfoca cocriação de conhecimento com os interessados e compartilhamento desse conhecimento para garantir utilização de pesquisas relevantes para facilitar tomada informada de decisões e mudanças na política, prática e prestação de serviços de saúde. No Brasil, existem muitos desafios para implementar a translação do conhecimento: falta de familiaridade; falta de parceria entre pesquisadores e usuários do conhecimento, e baixos orçamentos para pesquisa.

Conclusões: Uma ênfase na translação do conhecimento tem potencial para impactar positivamente resultados de saúde. Futuras investigações são necessárias no Brasil para estudar abordagens para melhorar o uso de resultados de pesquisa.

Palavras-chave: Disseminação de informação. Prática clínica baseada em evidências. Formulação de políticas.

\section{RESUMEN}

Objetivos: Estudio teórico-reflexivo de conceptos de traslación del conocimiento y proceso de implementación para la utilización de evidencias de investigación en la práctica y en la formulación de políticas.

Resultados: El proceso de traslación de la investigación a la práctica es interactivo y dinámico, con límites flexibles entre creación del conocimiento y desarrollo de acciones. La traslación del conocimiento enfoca coproducción de conocimientos con los interesados y compartir ese conocimiento para garantizar la utilización de investigaciones relevantes para facilitar decisiones informadas y cambios en políticas, prácticas y en el modo de brindar cuidados de salud. En Brasil existen numerosos desafíos para implementar la traslación del conocimiento: falta de familiaridad; falta de alianzas entre investigadores y usuarios del conocimiento; bajos presupuestos de investigación.

Conclusiones: Un énfasis en la traslación del conocimiento tiene potencial de impactar positivamente los resultados de salud. Se necesitan investigaciones futuras en Brasil para estudiar enfoques para mejorar el uso de los resultados de la investigación.

Palabras clave: Diseminación de información. Práctica clínica basada en la evidencia. Formulación de políiticas. 


\section{DINTRODUCTION}

Traditionally, the uptake of research into practice is slow often taking many years making innovation in health services delivery difficult and rendering some research findings obsolete. Furthermore, in Brazil and many other countries there are gaps between research, practice and policy (1-2); "between what is known and what is consistently done" ${ }^{\prime \prime(3)}$.

Nursing scientific knowledge has the potential to improve health outcomes and to advance innovative technologies in care, therefore it is necessary to accelerate the use of research results in policy and practice. Although there is an increasing recognition of the need to make research findings accessible to potential users, barriers such as time and the abundance of new information have been described ${ }^{(4-5)}$. This trend is evident in nursing and health services research where efforts have been developed to disseminate research findings more effectively, and to adopt evidence-based decision-making in clinical practice and policy-making ${ }^{(4)}$.

The interest in knowledge translation (KT) has increased in recent years due to recognition that it is critical to relevant knowledge development, dissemination, and uptake of research results. New knowledge, in of itself, does not lead to broad application nor effect health outcomes ${ }^{(6)}$. Uptake of research results will facilitate improved outcomes for patients ${ }^{(7-8)}$, as well as address outcomes at the provider and system levels.

$\mathrm{KT}$ is a relatively new field and remains unclear in Brazil. Research usually does not focus on the implementation of a change in practice, even though there have been many publications regarding the need to use evidence to improve the quality of health care and the formulation of health policy ${ }^{(2,9)}$. Considering this context, the following question emerged: What are the possibilities for knowledge translation to improve utilization of research results in policy and practice?

This paper provides a theoretical-reflective study of knowledge translation concepts and their implementation processes to use research evidence in policy and practice. This reflection is based on the Knowledge-to-Action (KTA) process, a conceptual framework that outlines key elements for $K T^{(8)}$. $K T^{\prime}$ 's concepts are first described and then the KTA conceptual framework is presented, outlining important steps to implement KT. Some challenges to implementing $\mathrm{KT}$ in Brazil are also discussed. This paper will provide considerations on $\mathrm{KT}$ that will be useful for Brazilian researchers, providers, decision-makers and policy-makers.

\section{KNOWLEDGE TRANSLATION CONCEPTS}

$\mathrm{KT}$ is a broad concept, encompassing all steps between the creation of knowledge and its application to yield beneficial outcomes for society ${ }^{(10)}$. KT moves beyond the simple dissemination of knowledge into actual knowledge use. Terms such as knowledge creation and knowledge dissemination do not fully describe the use of knowledge in practice ${ }^{(7)}$.

The Canadian Institutes of Health Research (CIHR) define $K T$ as "a dynamic and iterative process that includes the synthesis, dissemination, exchange and ethically sound application of knowledge to improve health, provide more effective health services and products and strengthen the healthcare system" ${ }^{\prime \prime 111)}$. Although the CIHR definition is commonly used in Canada, it has been adapted by others, including the World Health Organization $(\mathrm{WHO})^{(7)}$.

Two main categories of KT have been identified: integrated $\mathrm{KT}$ and end-of-grant $\mathrm{KT}^{(6)}$. Integrated $\mathrm{KT}$ incorporates knowledge-users throughout all research processes. Knowledge-users are individuals or groups who are able to use the evidence generated through research to make informed decisions about health policies, programs and practices. Examples of knowledge-users include health care providers, policy-makers, educators, health care administrators and managers, community leaders, or patients. Using integrated KT strategies will ensure more relevant research and ultimately better uptake of research results ${ }^{(6)}$.

End-of-grant KT refers to those activities that mainly occur at the end of a study to disseminate research results to a variety of audiences. Activities can vary significantly and include both traditional approaches (e.g., conference presentations, peer-reviewed articles) but could also include activities such as videos, media articles, or a toolkit for a specific topic area(6).

\section{KNOWLEDGE-TO-ACTION FRAMEWORK}

The increasing recognition of the importance of $\mathrm{KT}$ has led to the development of several theories and frameworks. One such framework is the Knowledge-to-Action process $^{(8)}$ as shown in Figure 1.

The model contains the knowledge creation cycle, illustrated by the funnel to refine knowledge and make it more useful, and the action cycle illustrating the process of knowledge application ${ }^{(10)}$. The KT process is iterative and dynamic, rather than linear. It has fluid boundaries between knowledge creation and action components ${ }^{(8)}$. One may start at the identification of the problem but within 


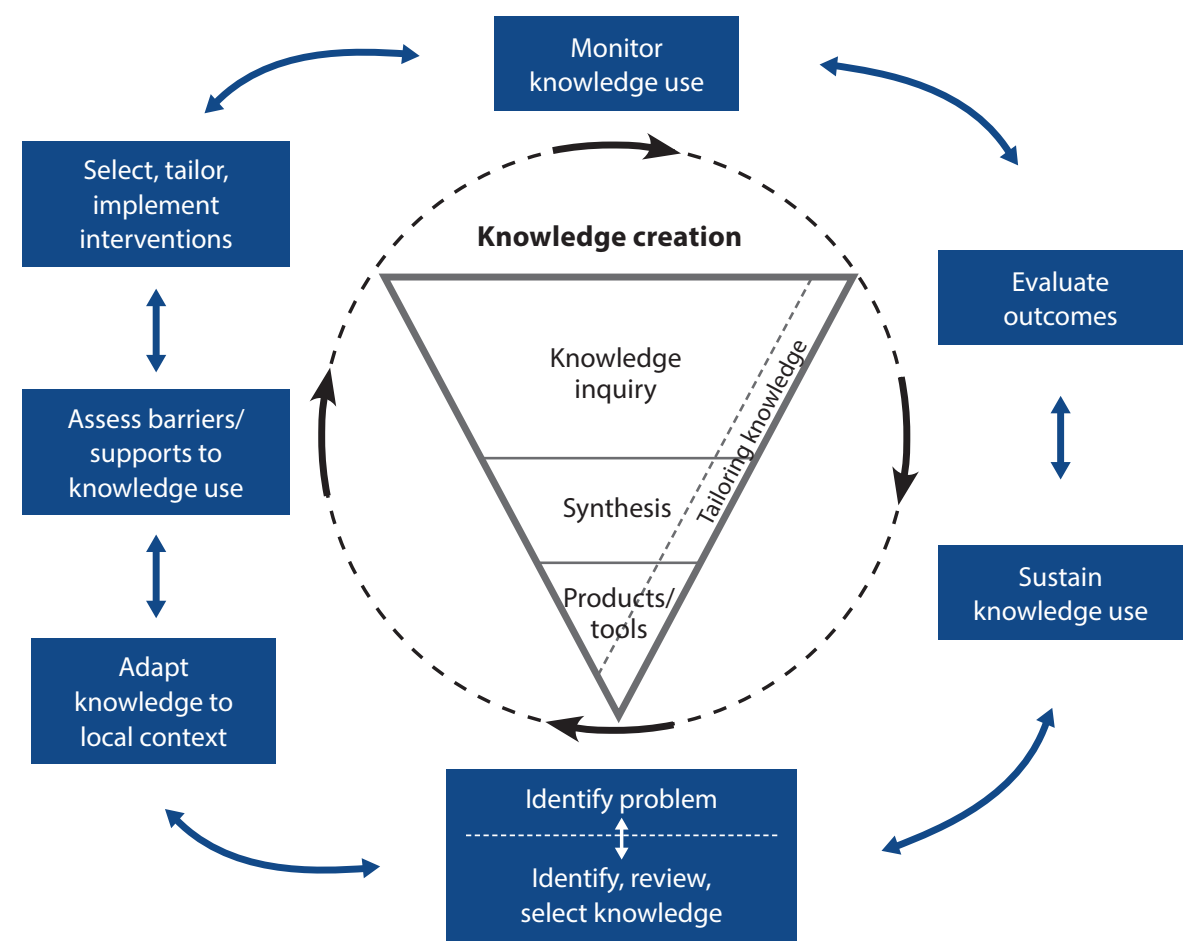

Figure 1 - Knowledge-to-Action process. Malden, United States, 2006 Source: Graham, Logan, Harrison, Straus, Tetroe, Caswell, et al., 2006 (18). Used with permission.

the framework you may move from one step to the next and back again to facilitate uptake of knowledge.

\section{KNOWLEDGE TRANSLATION IMPLEMENTATION}

The development of a KT plan is essential when starting a new research project. Comprehensive and flexible templates are available to assist, such as the Knowledge Translation Planning Template ${ }^{(12)}$ and Guide to Knowledge Translation Planning at $\mathrm{ClHR}^{(6)}$.

Involving knowledge-users at beginning of the process ensures more relevant research and ownership, which will assist in facilitating uptake of research results. Knowledge-users can assist in identifying a research problem relevant to policy and practice. Once an issue is identified, research team members and knowledge-users can work together to develop the research questions to ensure the essence of the problem is captured. Knowledge-users can also take an active role in the development of a KT plan providing input into what types of approaches would likely work best and contributing to how best to collect data. They can provide information on the context that researchers may not have.

According to the KTA framework, the process may start with knowledge creation, an important phase to synthesize knowledge and make it more useful to end-users. It may include primary research or synthesis of results from other studies and reports. It also considers creation of knowledge tools or products, such as practice guidelines or algorithms ${ }^{(8)}$.

The action cycle is composed of seven phases focusing on activities needed for knowledge to be applied in health care systems. It includes the identification of the problem through planning for sustainability of knowledge use in policy and practice ${ }^{(8)}$. Adapting knowledge to the local context, assessing barriers and facilitators to its use and tailoring knowledge to the needs of people who are going to use it is crucial.

With regards to KT interventions, a variety of strategies can be used. In addition to more traditional academic approaches such as conference presentations and peer-reviewed articles other initiatives can also be used, such as educational outreach visits, educational meetings, deliberative dialogues, policy briefs, newsletters, videos, websites, blogs, social media, patient stories, and artistic approaches (e.g., paintings, poems). Multiple strategies are commonly used. It is important to consider the target audience and messages, and the goal of KT activities (e.g., awareness, practice change, policy change).

The research budget must also be considered. Some KT activities require a significant budget, while others are less 
expensive or can be completed at no cost. More expensive options are not necessarily more effective.

It is important to monitor the use of the knowledge, determining the diffusion of the knowledge to targeted knowledge-user groups ${ }^{(8)}$ and considering how knowledge is being used and the outcomes of the knowledge use $\mathrm{e}^{(5)}$.

The importance of evaluating outcomes is critical to determine the effectiveness of the KT plan. Evaluation should consider outcomes at the patient, provider, and system levels $s^{(5)}$. The complexity of measuring change cannot be underestimated.

Planning for sustainability of knowledge use in policy and practice is important and should begin at the start of a research project. Ponder barriers to the retention of practice change and further uptake of research results. Reflect on questions such as how can we maintain the change, how can change be scaled up to other areas, and what contextual factors do we need to consider to facilitate retention and further uptake ${ }^{(13)}$ ? Finally, one needs to consider the sustainability for KT initiatives. Sustainability is seldom considered in KT plans and most often first addressed at the end of the research process ${ }^{(13)}$.

\section{GT IN THE BRAZILIAN CONTEXT}

Implementing KT in Brazil is both a need and a challenge. There are many barriers to disseminating and using research results in the Brazilian health care setting. International literature describes barriers such as lack of awareness, lack of tools, lack of agreement with the evidence or research results, perceived lack of value and benefit to changing practice, lack of practicality, lack of time, and lack of motivation ${ }^{(1,14-15)}$.

In Brazil, the first barrier is the overall lack of awareness and familiarity with KT. Reviewing KT literature may assist in better understanding its implementation, as well as identifying potential barriers and solutions. Furthermore, it will be necessary to develop or adapt KT models and frameworks to the Brazilian context.

Another challenge is the identification of a problem. Researchers should begin by re-evaluating if a proposed research study will contribute not only to the development of new knowledge but to translate that knowledge into practice. Researchers should be aware of the interests and needs of providers, decision-makers and policy-makers.

There is also little involvement of key stakeholders ${ }^{(15)}$ and lack of partnership between researchers and knowledge-users in the research process. Most of the research groups in nursing have no legitimate connection with the systems responsible for health practices ${ }^{(9)}$. An approach that includes both researchers and knowledge-users is needed to fill the gap between research and practice. The researcher cannot do KT alone. It is necessary to engage stakeholders to facilitate the uptake of research results and ensure practice and policy changes are indeed happening.

Finally, research budgets are often small with limited ability to develop and implement a KT plan. Even so, it is important to include KT in research budgets. Research funding agencies have an important role to encourage KT by their funding recipients ${ }^{(15)}$. In Canada, the majority of funding institutions require research proposals to have a plan for KT activities. In Brazil, there is little focus on KT by funding agency policies; advocacy to promote the importance of KT and the associated costs will be needed.

\section{口 FINAL CONSIDERATIONS}

This paper has provided a theoretical-reflective study of knowledge translation concepts and their implementation processes for using research evidence in policy and practice. We have also included challenges to implementing KT initiatives in Brazil.

KT focuses on co-creating knowledge with stakeholders and sharing that knowledge to ensure uptake of research results thereby facilitating change in policy, practice and health services delivery. If KT approaches are not used, the success of uptake of research results may be more limited. The KTA framework is an important conceptual framework that assists those concerned with KT implementation, delivering sustainable, evidence-based interventions.

In Brazil, many challenges exist in implementing KT, including lack of awareness, difficulties in identifying relevant research problem, little involvement of key stakeholders and lack of partnerships between researchers and knowledge-users in research process, low research budgets and little focus on KT by funding agency policies. Future research in Brazil is needed to adapt KT frameworks to the Brazilian context and to study innovative KT approaches to improve the uptake of research results.

\section{REFERENCES}

1. Grimshaw JM, Eccles MP, Lavis JN, Hill SJ, Squires JE. Knowledge translation of research findings. Implement Sci. 2012;7:50.

2. Padilha MIC. Translational research: what is its importance to nursing practice? Texto Contexto Enferm. 2011 Jul-Set;20(3):219-20.

3. Bhattacharyya 0 , Reeves $S$, Zwarenstein M. What is implementation research? rationale, concepts, and practices. Res Soc Work Pract. 2009;19(5):491-502.

4. Pereira ER. Translation of knowledge and translational research in healthcare. J Nurs UFPE on line. 2013;7(3):1-3. 
5. Straus SE, Tetroe J, Graham ID, Zwarenstein M, Bhattacharyya O, Shepperd $S$. Monitoring use of knowledge and evaluating outcomes. CMAJ. 2010;182(2):E94-E98.

6. Canadian Institutes of Health Research. Guide to Knowledge Translation Planning at CIHR: integrated and end-of-grant approaches [Internet]. 2012 [cited 2015 Mar 8]. Available from: http://www.cihr-irsc.gc.ca/e/documents/kt_ Im_ktplan-en.pdf.

7. Straus SE, Tetroe J, Graham ID. Knowledge translation is the use of knowledge in health care decision making. J Clin Epidemiol. 2011 Jan;64(1):6-10.

8. Graham ID, Logan J, Harrison MB, Straus SE, Tetroe J, Caswell W, et al. Lost in knowledge translation: time for a map? J Contin Educ Health Prof. 2006;26(1):13-24.

9. Trentini M, Silva DMGV. Research groups in nursing: from knowledge transfer to the practice. Texto Contexto Enferm. 2012 out-dez;21(4):723-4.

10. Tetroe J. Knowledge Translation at the Canadian Institutes of Health Research: a primer. Focus Technical Brief. 2007;18:1-8.
11. Canadian Institutes of Health Research. More about knowledge translation at CIHR: knowledge translation definition [Internet]. 2014 [cited 2015 Apr 2015]. Available from: http://www.cihr-irsc.gc.ca/e/39033.html

12. Barwick, M. Knowledge translation planning template [Internet]. Toronto, Ontario: The Hospital for Sick Children; 2013 [cited 2015 Mar 8]. Available from: http://www.melaniebarwick.com/dlKT.php?f=KT_Planning_Template_Fillable_Form_2014.pdf

13. Davies B, Edwards N. Sustaining knowledge use. In: Straus S, Tetroe J, Graham ID, organizers. Knowledge translation in health care moving from evidence to practice. West Sussex, UK: Blackwell Publishing Ltd.; 2009. p. 165-173.

14. Gravel K, Légaré F, Graham ID. Barriers and facilitators to implementing shared decision-making in clinical practice: a systematic review of health professionals' perceptions. Implement Sci. 2006, 1:16.

15. Cordero C, Delino R, Jeyaseelan L, Lansang MA, Lozano JM, Kumar S, et al. Funding agencies in low-and middle-income countries: support for knowledge translation. Bull World Health Organ. 2008 Jul;86(7):524-34.

\section{Author's address:}

Maria Alice Dias da Silva Lima

Rua São Manoel, 963/208, Rio Branco

90620-110 Porto Alegre - RS

E-mail: malice@enf.ufrgs.br
Received: 23.04.2015

Approved: 14.07.2015 